\title{
ASSESSMENT OF TOXIC METAL CONTAMINATION LEVEL AND ITS CHEMICAL SPECIATION IN AN URBAN ENVIRONMENT BY ROADSIDE TREE BARK MONITORING
}

\author{
Bijoy Sankar Goswami ${ }^{\bowtie}$, Tanmoy Kalita and Hrishikesh Sarma \\ Department of Chemistry, B. Borooah College, Ulubari, Guwahati- 781007, Assam, India \\ ${ }^{\otimes}$ Corresponding Author: bijoysgoswami@gmail.com
}

\begin{abstract}
Roadside tree bark is an essential bio-monitor to assess the quality of the urban air environment. Due to the toxic properties of trace metals, it becomes lethal for non-human and humans biota, particularly in urban areas. The principal objective of this research has been to resolve the contamination of roadside tree bark in Guwahati and to specify their potential origin sources. In total 20 tree barks as well as deposited road dust samples were collected from 20 different locations of five various land use kinds covering Industrial, City Roadside, Commercial, Sensitive and National Highway Side within the Guwahati city roads characterized through varying vehicular traffic intensity. The heavy metal contamination in the roadside tree bark samples followed the order as $\mathrm{Fe}>\mathrm{Zn}>\mathrm{Mn}>\mathrm{Pb}>\mathrm{Co}>\mathrm{Cu}>\mathrm{Ni}>\mathrm{Cd}>\mathrm{Cr}$ while the road dust follows $\mathrm{Cd}<\mathrm{Co}<\mathrm{Pb}<\mathrm{Cr}<\mathrm{Cu}<\mathrm{Ni}<\mathrm{Zn}<\mathrm{Mn}<\mathrm{Fe}$. The chemical speciation study in tree bark samples showed that $\mathrm{Fe}$ along with $\mathrm{Mn}$ is combined to Fe-Mn oxide fraction, $\mathrm{Pb}$ along with $\mathrm{Ni}$ is mostly associated with the replaceable fraction and $\mathrm{Cd}, \mathrm{Zn}, \mathrm{Cu}$ are destined to organic matter as well as Co to the residual or lattice fraction. The contamination level was evaluated with extensively established several pollution indices. Most of the indices showed that the tree barks were significantly polluted with $\mathrm{Pb}, \mathrm{Zn}, \mathrm{Cu}, \mathrm{Ni}, \mathrm{Cd}$, and which is linked with anthropogenic factors (motor Traffic). The potential ecological risk in different zone showed the order National Highway Roadside $>$ City Roadside $>$ Commercial $>$ Industrial $>$ Sensitive.
\end{abstract}

Keywords: Heavy Metals, Tree Bark, Chemical Speciation, Pollution Indices

RASĀYAN J. Chem., Vol. 14, No.3, 2021

\section{INTRODUCTION}

Heavy metals can come from several various causes in urbanized regions. In an urban environment, vehicular emissions are a major source for heavy metal exposure ${ }^{1-3}$ Heavy metals that appeared in street dust like $\mathrm{Ni}, \mathrm{Cu}, \mathrm{Cr}, \mathrm{Zn}, \mathrm{Cd}, \mathrm{Mn}$, along $\mathrm{Pb}$ are important for environmental pollution. As per the types of vehicles in traffic, the type and quantity of heavy metals differ from street dust. Heavy metal may gather on top of the soil from atmospheric deposition through interception, impaction and sedimentation. Pollution due to heavy metals from atmospheric deposition in urban regions is mainly indicated by road dust and topsoil and its persistence in the soil is a long practice. Lead as well as other dust metals are the main reason for the pollution near the roadside due to heavy traffic.,

Following expression gives an easy mass balance of heavy metals in the soil: 6,7

$$
\mathrm{M}_{\mathrm{total}}=\left[\mathrm{M}_{\mathrm{p}}+\mathrm{M}_{\mathrm{a}}+\mathrm{M}_{\mathrm{f}}+\mathrm{M}_{\mathrm{ag}}+\mathrm{M}_{\mathrm{ow}}+\mathrm{M}_{\mathrm{ip}}\right]-\left[\mathrm{M}_{\mathrm{cr}}+\mathrm{M}_{\mathrm{l}}\right]
$$

Here, heavy metal is represented by " $M$ ", " $p$ " represents parent material, atmospheric deposition is represented "a", where "f" belongs to fertilizer sources, agrochemical sources is showed by "ag", organic waste sources is represented by "ow", inorganic pollutants is showed by "ip", "cr" represents crop removal, as well as leaching losses and volatilization, are represented by "l". It's proposed the anthropogenic emission towards the environment for many heavy metals, is 3 orders of magnitude more compared to healthy fluxes. ${ }^{8}$ Anthropogenic resources produced more heavy metals and are usually more bioavailable as compared to lithogenic or pedogenic. ${ }^{9,10}$ Heavy metal can build up grow barks from atmospheric deposition through interception, sedimentation as well as impaction. Plants growing in areas with clean air but showing elevated heavy metals in the roots are probably being exposed in the sediments and soils in which they are growing. ${ }^{11}$ 
RASĀYAN J. Chem.

Vol. 14 | No. 3 |1617-1628| July - September | 2021

Moreover, the uptaking of metal is dependent upon species of plants as well as affected by elements' interactions in soil solution. Metals are taken through plants from soil and are considered as the main path for measuring the risk of chemical impurities in soil. ${ }^{12}$ In soil, the existence of toxic metals may rigorously inhibit the biodegradation of natural pollutants. Metal contaminated soil can lead to various hazards as well as risk to the ecosystem along with human through different ways such as direct consumption or contact with a decrease in land usability for cultivation, phytotoxicity, consuming polluted groundwater, "soil-plant - human or soil-plant - animal-human" food chain, polluted soil. ${ }^{13-15}$

The total concentration of heavy metal in the environment cannot give full information about the toxicity, bioavailability as well as capacity for remobilization risk for heavy metals. Nevertheless, only bioavailability prediction is known for heavy metals due to their chemical speciation. There are also some other factors such as bonding strength, both in complexed or free ionic form through natural material or integrated into the mineral portion of test. The focus or target in the research work is for checking the concentration levels of heavy metals in tree bark along with clarification of the chemical present in the environment, due to the good relation between speciation as well as toxicity. There are many extraction schemes presents to separate various chemical phases with which the metal is linked in various amounts. ${ }^{16,17}$

\section{Site Description and Sampling}

\section{EXPERIMENTAL}

In this research work, Guwahati has been chosen to monitor the urban tree bark regarding trace metal composition ("91033'E-91 $52^{\circ} \mathrm{E}$ and $26^{\circ} 08^{\prime} \mathrm{N}-26^{0} 14^{\prime} \mathrm{N}$ "). Guwahati is the capital of Assam, India.

Assam is encompassed by the Brahmaputra River that is the biggest river in the whole world, in the north as well as the southern part it is covered by little and medium hills. This kind of hill shows up in nearly all aspects of the community, which has a complete part of $231 \mathrm{~km}^{2}$ for the present population of about 3.2 million. The community may be the primary corridor for passage on the neighboring 7 states of India with the 2 freeways NH37 and NH31 passing through the community, are active with vehicular traffic morning and evening. Most of the roads are narrow in comparison to the volume of plying vehicles due to unplanned construction and rapid haphazard growth. Traffic jams have become very common even.

The roadside tree bark samples (Table-1) were collected along with the major ways in Guwahati. Five different kinds of zones were chosen for this study. These zones are located along (i) Industrial area with medium traffic (ii) City roadside located on the highly trafficked road (iii) Commercial and nonindustrialized area with high traffic (iv) Sensitive zone having university with medium traffic (v) National Highway Roadside (NH37) with highly trafficked. In total 20 locations were chosen covering all the five zones (Fig.-1), and from every location, approximately (length $=12 \mathrm{~cm}$ and breath $=8 \mathrm{~cm}$ ) a thin layer of roadside matured tree bark samples at $150-200 \mathrm{~cm}$ height above ground. Again, several deposited street dusts on the roots were also collected and mixing them thoroughly to make a composite sample from each location of the same tree. ${ }^{19}$ Samples have been transmitted in Polythene bags aseptically to the laboratory as well as wiped in a shade lumps have been damaged along with the fraction passing through $\sim 94 \mu \mathrm{m}$ sieve has been preserved for this research. ${ }^{18}$

Table-1: Various Street Dust and Tree Bark (with Local and Scientific Name) Samples collected from Different Zones of Guwahati

\begin{tabular}{|c|c|c|c|c|}
\hline \\
\hline S. No. & Sampling Locations & Type & Local Name & Scientific Name \\
\hline 1 & Noonmati (Near Petrol Depot) & \multirow[t]{5}{*}{ Industrial } & Mirzari & Casia siamea Lamk. \\
\hline 2 & Noonmati-Chunsali Road & & Banyan tree & Ficus bengalensis \\
\hline 3 & Noonmati (Near Refinery) & & Jack Fruit & Artocarpus \\
\hline 4 & Bamunimaidan (Udyog Bhawan) & & Bakul & Mimusops elengi \\
\hline 5 & Bamunimaidan(Industrial Estate) & & Jamun & Syzygium cumini \\
\hline 6 & Chandmari(Near City Bus Stop) & \multirow{4}{*}{$\begin{array}{l}\text { City Road } \\
\text { Side }\end{array}$} & Indian Rubber tree & Ficus elastica Rscto \\
\hline 7 & Goswami service & & Mast tree & Polyalthia longifolia \\
\hline 8 & Silpukhuri bus stop & & Mango tree & Mangifera indica \\
\hline 9 & Guwahati club Bus Stop & & Bakul & Mimusops elengi \\
\hline 10 & Fancy Bazar (Near Market Area) & Commercial & Aahat & Ficus religiosa Linn \\
\hline
\end{tabular}


RASĀYAN J. Chem.

Vol. 14 | No. 3 |1617-1628| July - September | 2021

\begin{tabular}{|c|c|c|c|c|}
\hline 11 & Kalipur (Sanitary \& Marble Shop ) & & Jack Fruit & Artocarpus \\
\hline 12 & Nursery (Near Aluminum Shop) & & Kadam & Anthocephalus \\
\hline 13 & Adabari (Near bus terminus) & & Bakul & Mimusops elengi \\
\hline 14 & Jalukbari (Near Gauhati University) & \multirow[t]{3}{*}{ Sensitive } & Red Gum & Eucalyptus \\
\hline 15 & Jalukbari (Near GU SBI) & & Kuros & Derris indica Bennet. \\
\hline 16 & Jalukbari (Near Samanay Khetra) & & Bakul & Mimusops elengi \\
\hline 17 & Basistha (Near Oza Hyundi) & \multirow{4}{*}{$\begin{array}{c}\text { NH } 37 \\
\text { Road Side }\end{array}$} & Jack Fruit & Artocarpus \\
\hline 18 & Basistha Chariali ( City Bus Stop) & & Queens Flower & Lagerstroemia \\
\hline 19 & Basistha (Near petrol pump) & & Rain tree & Samanea saman \\
\hline 20 & Sarusajai (Near game village) & & Teok & Tectona grandis Linn. \\
\hline
\end{tabular}

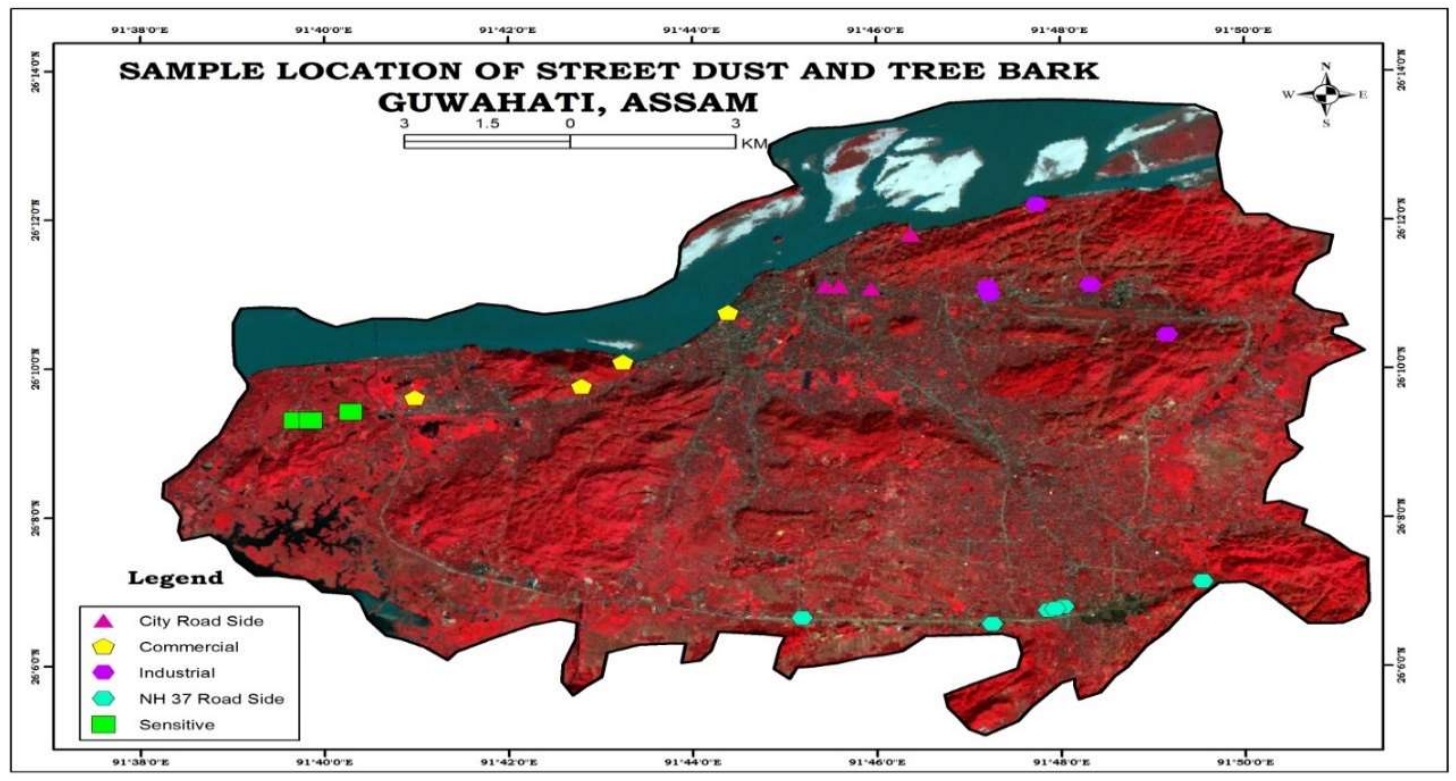

Fig.-1: Various Road Dust and Tree Bark Sampling Locations at Different Zones of Guwahati

\section{Plant Barks Sample Preparation}

Plant barks samples were gently washed with deionized distilled water for near about 3 minutes from removing soil and dust particles followed to the plants. Samples of plants have been dried in the air after washing for 2 weeks at room temperature. ${ }^{19}$ All plant samples have been dried oven at $70-80^{\circ} \mathrm{c}$ as well as it was ground to fine powders by using a domestic mixer grinder ${ }^{19}$ and sieved in a $0.2 \mathrm{~mm}$ sieve. Every sample of the plant has been stored in a plastic bag with clean self-sealing.

$1 \mathrm{~g}$ of dried plant material has been taken in a conical flask $(100 \mathrm{ml})$. Subsequently, $0.5 \mathrm{ml} 60 \% \mathrm{HClO}_{4}$, $2.5 \mathrm{ml} \mathrm{HNO}_{3}$ as well as $0.5 \mathrm{ml} \mathrm{H}_{2} \mathrm{SO}_{4}$ have been mixed to it. The solution was heated at a low temperature. Increased the heat and digested for 15-20 minutes till white fumes were evolved. Cooled and filtered and made up the final volume to $1000 \mathrm{ml}$ after several washings of filter paper by a small portion of distilled water. The extract was light pink. ${ }^{20}$

\section{Extract for Deposited Road Dust Samples}

The dust samples were digested in triacid mixture (1:2:4; $\mathrm{HNO}_{3}, \mathrm{HClO}_{4}$ and $\left.\mathrm{H}_{2} \mathrm{SO}_{4}\right), 1 \mathrm{~g}$ dust sample + $30 \mathrm{ml}$ acid mixture heated to dryness, cooled (White residue was obtained) $10 \mathrm{ml}$ of $1: 1 \mathrm{HCl}+40 \mathrm{ml}$ distilled water were added to it filtered by Whatman No.40 filter paper volume of the filtrate has been made up to $100 \mathrm{ml}$. The extract was ready to analyze heavy metals $\mathrm{Co}, \mathrm{Ni}, \mathrm{Mn}, \mathrm{Cd}, \mathrm{Zn}, \mathrm{Cu}, \mathrm{Cr}$, Fe, along with $\mathrm{Pb}^{20-22}$

\section{Sequential Extraction for Chemical Metal Speciation}

The Procedure of sequential extraction ${ }^{23-27}$ is utilized in this speciation. Every chemical fraction of $\mathrm{Zn}, \mathrm{Cr}$, $\mathrm{Ni}, \mathrm{Fe}, \mathrm{Cu}, \mathrm{Co}, \mathrm{Cd}$ and $\mathrm{Pb}$, the in-plant sample is operationally defined as follows: 
- $\mathrm{F}_{1}$ (Exchangeable fraction linked with carbonated stages),

- $\mathrm{F}_{2}$ (Carbonate bound fraction)

- $\mathrm{F}_{3}$ (Reducible fraction or fraction connected with oxides of Fe as well as Mn)

- $\mathrm{F}_{4}$ (Oxidisable fraction bound to organic matter)

- $\mathrm{F}_{5}$ (Residual or lattice metals).

This process involved:

(i) extraction with $10 \mathrm{ml}$ of $\mathrm{MgCl}_{2}(1.0 \mathrm{M})$ buffered at $\mathrm{pH} 7.0$ shaking continuously at $300 \mathrm{~K}$ for 1 hour for obtaining $F_{1}$,

(ii) treating the residue from (1) with $10 \mathrm{ml} \mathrm{CH}_{3} \mathrm{COONa}(1.0 \mathrm{M})$ (at $\mathrm{pH} 5.0$ with acetic acid) at $300 \mathrm{~K}$ for 5 hour for extracting $\mathrm{F}_{2}$ fraction.

(iii) treating the residue from (2) with $20.0 \mathrm{ml}$ of $\mathrm{NH}_{2} \mathrm{OH} . \mathrm{HCl}(0.04 \mathrm{M})$ dissolved in acetic acid $(25 \%(v / v))$ at $370 \mathrm{~K}$ and stirring until complete dissolution to get the $\mathrm{F}_{3}$ fraction.

(iv) mixing the residue from (3) with $5.0 \mathrm{ml}$ of $\mathrm{H}_{2} \mathrm{O}_{2}(30 \%(\mathrm{v} / \mathrm{v}))$ and $3.0 \mathrm{ml}$ of $\mathrm{HNO}_{3}(0.02 \mathrm{M})$ (at $\mathrm{pH} 2.0$, adding more $\mathrm{HNO}_{3}$ if needed) and at $358 \mathrm{~K}$ heated for 2 hours with alternating agitation, cooled at room temperature, after that again mixed with $3.0 \mathrm{ml}$ of $\mathrm{HNO}_{3}(0.02 \mathrm{M})$ along with $5.0 \mathrm{ml}$ of $\mathrm{H}_{2} \mathrm{O}_{2}(30 \%(v / v))$ (adjusted to $\mathrm{pH} 2.0$ with $\mathrm{HNO}_{3}$ ) keeping the solution at $358 \mathrm{~K}$ for 3 hours and stirred, along with cool down and addition of $5.0 \mathrm{ml}$ of $\mathrm{CH}_{3} \mathrm{COONH}_{4}$ $(3.2 \mathrm{M})$ mixed with $\mathrm{HNO}_{3}(20 \%(v / v))$ diluted to $20 \mathrm{ml}$ and continuously stirring for next 30 minutes for obtaining $\mathrm{F}_{4}$ fraction, and

(v) digesting the residue from (4) with acid mixture containing $\mathrm{H}_{2} \mathrm{SO}_{4}, \mathrm{HNO}_{3}, \mathrm{HCl}$ (4:2:1) ratio for 3 hours until complete dissolution is formed, dilution with $100 \mathrm{ml}$ of double distilled water for getting the remaining $F_{5}$ fraction. ${ }^{28-30}$ The solubility and bioavailability of metals decreases generally as residual $<$ organic bound $<\mathrm{Fe}-\mathrm{Mn}$ oxide bound $<$ carbonate bound $<$ exchangeable. ${ }^{31}$

\section{Apparatus and Reagents}

Glassware used for extracting process has been firstly washed with $1 \% \mathrm{HNO}_{3}(\mathrm{v} / \mathrm{v})$ as well as detergent, washed completely with plain tap water and then distilled water. Immediately after every extraction action, the mixture was centrifuged at $6000 \mathrm{rpm}$ for 1 hour (Remi tools, Mumbai, India). Sequential extractions have been completed with the help of sample (1 gram each) powder along with sieved with a 100 mess sieve. Extractions have been completed in $25 \mathrm{ml}$ polypropylene centrifuge tubes, having a mechanical shaker for mixing the solutions as needed. To follow every extraction, the mixture has been centrifuged at $6000 \mathrm{rpm}$ for 1 hour, and also the supernatant solution has been separated by pipette. ${ }^{32}$ The supernatant solution was decanted into polythene plastic bottles and saved for analysis. The residue was cleaned in 10ml-distilled water and centrifuged again. Acid digestion has been performed in glass beakers (borosil). $10 \% \mathrm{HNO}_{3}$ was used for cleaning plastic wares. All of the reagents used were AnalaR quality or even far better. ${ }^{1,33}$

The concentrations of heavy metals which include $\mathrm{Pb}, \mathrm{Cd}, \mathrm{Ni}, \mathrm{Cu}, \mathrm{Mn}, \mathrm{Fe}, \mathrm{Cr}, \mathrm{Co}$, along with $\mathrm{Zn}$ have been estimated by Atomic Absorption Spectrophotometer (Agilent Spectra AAS 220) using Agilent calibration standards for every metal. ${ }^{24}$ Quantification of metals has been based on calibration curves of regular metals solution. The accuracy of the metallic analysis has been managed by incorporating triplicate samples to come down with analytical blanks as well as batches. ${ }^{34}$

\section{Environmental Pollution Indices}

The environmental contamination level with heavy metals as well as associated hazards have been evaluated by using several established indices. ${ }^{35}$

$$
\mathrm{Pi} \text { (Pollution index) is defined as: }{ }^{36}
$$

$$
\mathrm{Pi}=\mathrm{C}_{\mathrm{n}} / \mathrm{C}_{\text {ref }}
$$

Pollution indices $(\mathrm{Pi})$ indicated the pollution categories

$\mathrm{Pi}<1==$ Unpolluted

$\mathrm{Pi}=1-2==$ Pollution at Low Rate

$\mathrm{Pi}=2-3==$ Pollution at Moderate Rate 
RASĀYAN J. Chem.

Vol. 14 | No. 3 |1617-1628| July - September | 2021

$\mathrm{Pi}>3==$ Pollution at High Rate

(ii) following formula defines the ecological risk factor index. $\mathrm{Er}_{\mathrm{i}}=\mathrm{T}_{\mathrm{i}} \times \mathrm{C}_{\mathrm{n}} / \mathrm{C}_{\mathrm{ref}}$

Where $T_{i}$ represents the metal's toxic response factor. The specific metals demonstration variable toxicity amounts to humans. According to Hakanson and Soliman the various metal values are $\mathrm{Mn}-1, \mathrm{Zn}-1, \mathrm{~Pb}-5$, $\mathrm{Ni}-5, \mathrm{Cu}-5, \mathrm{Cr}-2$, and Cd-30 ${ }^{37,38}$ for calculating this index. ${ }^{35}$ There are 5 kinds of pollution that are wellknown: $>320$ (very high), $\mathrm{Er}_{\mathrm{i}}=160-320$ (high) $\mathrm{Er}_{\mathrm{i}}=80-160$ (considerable), $\mathrm{Er}_{\mathrm{i}}=40-80$ (moderate), and $<40$ (low).

(iii) The potential RI (ecological risk) is described as "the sum of the index of ecological risk factors $\left(\mathrm{Er}_{\mathrm{i}}\right)$ for metals in a given sample". ${ }^{35,38,39}$ There are 4 types of index as: ${ }^{37} \mathrm{RI}>$ 600(high), RI $=300-600$ (considerable), $\mathrm{RI}=150-300$ (moderate), and $\mathrm{RI}<150$ (low).

(iv) The Meta analytical analysis describes the correlation between soil heavy metal (HM) content with relative or actual plant heavy metal (HM) uptake. Mobility ratio (MR) is calculated to quantitatively characterize the origin and transfer of the elements. ${ }^{40,41}$ Mobility ratio that expresses the ratio of the plant HM has been up taken concerning HM in soil. ${ }^{42}$

$$
\mathrm{MR}=\mathrm{HM}_{\text {plant }} / \mathrm{HM}_{\text {soil }}
$$

It has been suggested that by calculating MR or 'Concentration factors CF' the uptake characteristics of plants are easier to understand. Four categories of the index are distinguished: ${ }^{43}$ plants enrich these HM $(M R>1)$, indifferent behavior of the plant towards these HM $(M R=1)$ and the plant excludes this HM from uptake $(\mathrm{MR}<1)$.

(v) The Mobility Factor (MF) defines "as the ratio of exchangeable $\left(\mathrm{F}_{1}\right)$, carbonate-bound $\left(\mathrm{F}_{2}\right)$ and reducible fractions $\left(\mathrm{F}_{3}\right)$ to the sum of all fractions" ${ }^{44,45}$. The MF in percentage is computed as: ${ }^{27,46}$

$$
\mathrm{MF}=\left(\mathrm{F}_{1}+\mathrm{F}_{2}+\mathrm{F}_{3}\right) \times 100 /\left(\sum \mathrm{F}\right)
$$

Here, the sum of every fraction is represented by $\sum$ F. Mobility Factor is defined as the measurement for potential mobility of a metal. ${ }^{47,48}$ When the mobility factor index value is high it shows that specific metal is present in a high mobility state along with high accessibility to biological schemes. ${ }^{32,46,47}$

\section{RESULTS AND DISCUSSION}

\section{Heavy Metals in Deposited Road Dust (Root) and Tree Bark}

The range of metal concentration, mean values, variation coefficient with geochemical background values for deposited road dust and tree bark samples of five different zones are presented in Table- 2 and Table-3. The mean concentration of heavy metals in road dust followed the order as $\mathrm{Cd}<\mathrm{Co}<\mathrm{Pb}<\mathrm{Cr}<\mathrm{Cu}<\mathrm{Ni}$ $<\mathrm{Zn}<\mathrm{Mn}<\mathrm{Fe}$ while the mean heavy metal concentration in tree bark samples may be organized as $\mathrm{Cr}<\mathrm{Cd}<\mathrm{Ni}<\mathrm{Cu}<\mathrm{Co}<\mathrm{Pb}<\mathrm{Mn}<\mathrm{Zn}<\mathrm{Fe}$. The variation of mean concentrations of heavy metals for both road dust and tree bark is shown in Fig.-2 excepting the Iron concentration as it was abruptly high in both cases. Among the 9 elements studied, the mean concentration of Fe, Mn and $\mathrm{Zn}$ were considerably higher, whereas lower concentration was observed for $\mathrm{Co}$ and $\mathrm{Cd}$ for both road dust and tree bark samples in five different zones. Soliman also reported a similar trend of heavy metal content in sediments. ${ }^{38}$

In the present study, the mean values of $\mathrm{Ni}$ and $\mathrm{Zn}$ in road dust exceed the geochemical background values (4 times on average) while $\mathrm{Cu}$ exceeded two times (Table-2). Though the presence of $\mathrm{Cd}$ in road dust was least in the order but it appeared considerably high compared to the geochemical background values and $\mathrm{Pb}$ content was marginally high. The other metals $\mathrm{Fe}, \mathrm{Mn}, \mathrm{Co}$ and $\mathrm{Cr}$ were much lower than the geochemical background values. The mean concentration of $\mathrm{Cu}, \mathrm{Cd}$ and $\mathrm{Zn}$ exceeded the maximum concentration $\left(\mathrm{Cu}-100, \mathrm{Cd}-3\right.$ and $\mathrm{Zn}-300 \mu \mathrm{g} \mathrm{g}{ }^{-1}$ dry soil) for road dust collected from city roadside and national highway zone. Ni exceeded the maximum concentration of $50 \mu \mathrm{g} \mathrm{g}^{-1}$ in dry soil ${ }^{17}$ for all the zones. It may be due to the high vehicular traffic which resembles the studies Ferguson, who reported that a higher concentration trend has been discovered on streets wherever traffic was more likely to undergo stop-start. ${ }^{49}$ Table- 2 indicates that the maximum concentration of $\mathrm{Pb}$ was well below the maximum geochemical background values $100 \mu \mathrm{g} \mathrm{g}^{-1}$ dry soil and it may be due to the introduction of unleaded petrol. ${ }^{50}$ 


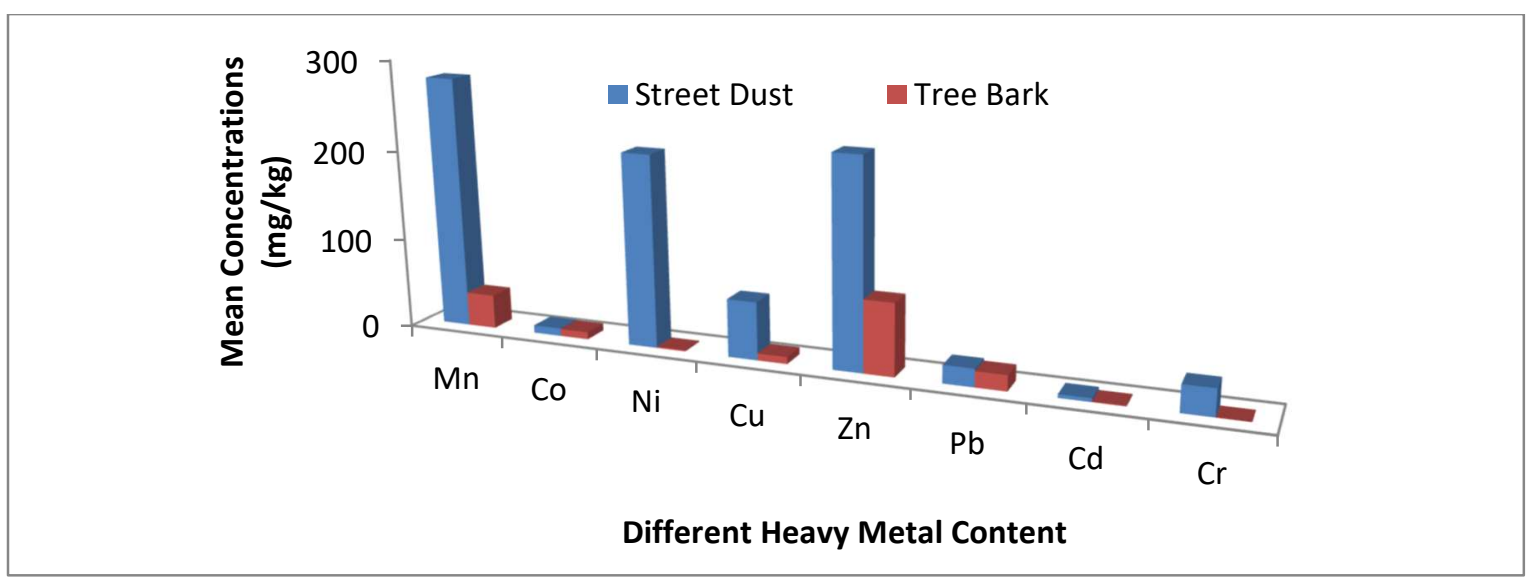

Fig.-2 : Variation of Mean Concentration of Heavy Metals in Deposited Road Dust and Tree Bark Samples

In the case of tree bark, most of the metals $\mathrm{Fe}, \mathrm{Mn}, \mathrm{Co}, \mathrm{Ni}$, and $\mathrm{Cd}$ were much lower in comparison to the geochemical background values except $\mathrm{Zn}$ (Table-3). The maximum concentration of almost all the metals was within the trigger concentration $\left(\mathrm{Zn}-130, \mathrm{Ni}-20, \mathrm{Cu}-50, \mathrm{~Pb}-100\right.$, and $\mathrm{Cd}-3, \mu \mathrm{g} \mathrm{g}^{-1}$ in air-dried soil. ${ }^{51}$ The lowest heavy metal content appeared in most road dust samples for sensitive zone and the highest appeared in the National Highway -37 zone (particularly $\mathrm{Mn}, \mathrm{Cu}, \mathrm{Pb}, \mathrm{Cd}, \mathrm{Zn}$ and $\mathrm{Cr}$ ). A similar trend was observed for tree bark also and the dominant metal was $\mathrm{Fe}, \mathrm{Mn}, \mathrm{Co}, \mathrm{Cu}, \mathrm{Zn}$ and $\mathrm{Cd}$ for the national highway zone. It has been observed that there was a high variation among the studied metals for both road dust and tree bark samples in five different zones. The variation coefficient (VC) Study in road dust (Table-3) displayed that $\mathrm{Cd}, \mathrm{Zn}, \mathrm{Cu}$, and $\mathrm{Mn}$, was in $\mathrm{VC}>50$ (a high variation level) while $\mathrm{Pb}$ and $\mathrm{Cr}$ were in the order $40>\mathrm{VC}>20$ (a minimum variation level) and the lowest variation was for $\mathrm{Ni}$ as well as $\mathrm{Co}(\mathrm{VC}<20)$. In the case of Tree bark, the highest variation appeared for $\mathrm{Mn}$ and $\mathrm{Ni}$ while $\mathrm{Cu}$ and $\mathrm{Zn}$ showed the minimum variation level. The variation was lowest in tree bark samples for $\mathrm{Co}, \mathrm{Pb}$ and $\mathrm{Cd}$ (Table-3). Martin et al. described that the higher the value of $\mathrm{VC}$ indicates the high anthropogenic influence. ${ }^{52}$

Table-2: Contents of Heavy Metal in Deposited Street Dust in Guwahati $\left(\mu \mathrm{g} \mathrm{g}^{-1}\right)$

\begin{tabular}{c|c|c|c|c}
\hline Metals & Range & Mean & Variation Coefficient (VC) (\%) & Geochemical Background $^{\text {a,b }}$ \\
\hline $\mathrm{Mn}$ & $36.1-818.8$ & 279.1 & 112 & $495^{\mathrm{a}}$ \\
\hline $\mathrm{Fe}$ & $17211-41201$ & 27174.4 & 41 & $37400^{\mathrm{a}}$ \\
\hline $\mathrm{Co}$ & $6.6-10.1$ & 8.5 & 16 & $10^{\mathrm{b}}$ \\
\hline $\mathrm{Ni}$ & $198.2-220.4$ & 212.3 & 5 & $50^{\mathrm{b}}$ \\
\hline $\mathrm{Cu}$ & $5.6-124.4$ & 63.8 & 68 & $20^{\mathrm{b}}$ \\
\hline $\mathrm{Zn}$ & $43-821.9$ & 229.2 & 145 & $50^{\mathrm{b}}$ \\
\hline $\mathrm{Pb}$ & $11.7-29.1$ & 19.9 & 32 & $20^{\mathrm{b}}$ \\
\hline $\mathrm{Cd}$ & $0.7-7.9$ & 4.0 & 85 & $1^{\mathrm{b}}$ \\
\hline $\mathrm{Cr}$ & $19.6-42.2$ & 29.5 & 31 & $50^{\mathrm{b}}$ \\
\hline
\end{tabular}

Table-3: Contents of Heavy Metal in Roadside Tree Bark in Guwahati $\left(\mu \mathrm{g} \mathrm{g}^{-1}\right)$

\begin{tabular}{c|c|c|c|c}
\hline Metals & Range & Mean & Variation Coefficient (VC) $(\%)$ & Geochemical Background a,b \\
\hline $\mathrm{Mn}$ & $14.3-67.3$ & 37.6 & 54 & $495^{\mathrm{a}}$ \\
\hline $\mathrm{Fe}$ & $138.3-435.4$ & 308.6 & 48 & $37400^{\mathrm{a}}$ \\
\hline $\mathrm{Co}$ & $6.5-9.0$ & 7.9 & 14 & $10^{\mathrm{b}}$ \\
\hline $\mathrm{Ni}$ & $0.1-2.8$ & 1.3 & 93 & $50^{\mathrm{b}}$ \\
\hline $\mathrm{Cu}$ & $6.2-10.5$ & 7.7 & 21 & $20^{\mathrm{b}}$ \\
\hline $\mathrm{Zn}$ & $41.1-105.2$ & 79.5 & 30 & $50^{\mathrm{b}}$ \\
\hline $\mathrm{Pb}$ & $13.9-21.8$ & 17.3 & 17 & $20^{\mathrm{b}}$ \\
\hline $\mathrm{Cd}$ & $0.7-1.1$ & 0.8 & 20 & $1^{\mathrm{b}}$ \\
\hline $\mathrm{Cr}$ & BDL & BDL & - & $50^{\mathrm{b}}$ \\
\hline
\end{tabular}

Geochemical Background ${ }^{\mathrm{a}, \mathrm{b}} 38,50$ 
Heavy metal in street dust is mainly initiated from multiple types of human activities such as tears and wear of vehicles, exhaust emissions, fuel ingestion, as well as industrial activity. ${ }^{53,54}$ In the whole world, $\mathrm{Cu}$ is at the $3^{\text {rd }}$ place for the utilization. ${ }^{55} \mathrm{Cu}$ is commonly utilized in vehicle oils. ${ }^{56} \mathrm{Cu}$ may also come to the roadside environment as a consequence of rusting of car parts such as metals etc. and wear of motor oil pumps ${ }^{35,57}$ along with tear and wear of engine. ${ }^{56,58} \mathrm{Cd}$ and $\mathrm{Zn}$ are connected with the wear of tire along with $\mathrm{Zn}$ particularly resulted in spills on the surface of road. ${ }^{59} \mathrm{Cd}$ is also significantly used in the production of $\mathrm{Ni} / \mathrm{Cd}$ rechargeable batteries.

$\mathrm{Zn}$ can disrupt the activity of soils, as it adversely influences the activity of earthworms and microorganisms, therefore retarding the description of organic and the natural matter is important ${ }^{32}$. The mobility of $\mathrm{Cr}$ is dependent upon sorption soil's attributes, such as clay material, organic material as well as the presence of iron oxide. The leachability of $\mathrm{Cr}$ is directly proportional to soil $\mathrm{pH}^{60}$. $\mathrm{Ni}$ is an element that happens on the planet just at really low levels and it is vital in doses that are little though it is harmful if exceeds the tolerance limit. ${ }^{60}$

This research work described the presence of heavy metals and their toxicity to humans as well as plants. Ingestion along with Inhalation is the 2 major exposure routes to toxic elements. It has been reported that $\mathrm{Pb}$ gathers in the human body such as the brain that can lead to death or poisoning. Lead also affects the central nervous system, kidneys, gastrointestinal tract, IQ, mental deterioration. ${ }^{60}$ Generally, plants cannot accumulate or absorb lead, but there is a high risk of lead-contaminated dust or soil deposits on the plants instead of taking lead through plants. ${ }^{60}$

$\mathrm{Cd}$ is quite bio-resistant, once assimilated by an organism is still resident for numerous years. The main risk to human health because of $\mathrm{Cd}$ toxicity is a chronic buildup of the kidneys triggering kidney dysfunction, neoplastic changes as well as hypertension. ${ }^{35}$ The toxicity of $\mathrm{Ni}$ and $\mathrm{Cu}$ is minor though humans are susceptible to the bioaccumulation of these metals assimilated into the entire body through the breathing system. ${ }^{35,61} \mathrm{Cu}$ is a vital micronutrient essential in the development of both animals as well as plants. In humans, it can help in the generation of blood hemoglobin. $\mathrm{Cu}$ is particularly crucial in water regulation, disease resistance along seed generation in Plants. ${ }^{60} \mathrm{Cu}$ is considered an essential element, but excessive doses may also cause intestinal and stomach irritation, kidney and liver damage, anemia. ${ }^{60} \mathrm{Ni}$ is not recognized for accumulating in animals or plants but Ni toxicity can cause various types of cancer in human bodies. Several of the signs related to ailments from extra nickel coverage such as cough, giddiness, headache, virtual disturbances, stomach upset, vomiting and nausea. ${ }^{60} \mathrm{Mn}$ deficiency might result in diabetes mellitus, epilepsy, and osteoporosis, while neurological toxicity is related to excessive manganese. ${ }^{60} \mathrm{Zn}$ is among the important heavy metals. Due to its deficiency ensuing from malabsorption, alcoholism, and diet might result in dwarfism, dermatitis and hypogonadism whereas unnecessary awareness within the body might result in nausea, electrolyte imbalance and anemia. ${ }^{60,62}$

\section{Assessment of Bioavailability of Heavy Metals in Tree Barks}

The metal contamination and its potential hazard were assessed based on the total metal concentration obtained by total acid digestion of the plant materials. All the studied heavy metals may not be bioavailable, thus the tree bark samples have been sequentially extracted to measure the chemical metal speciation and as a consequence give an indication of bioavailability and mobility of heavy metals.

The metal speciation in tree bark samples (Table-4) showed that the Fe (43\%) and Mn (34\%) was mostly connected with Fe-Mn oxide fraction respected through the least easily available fraction organic matter or sulphide fraction (Fe-21\%, Mn-26\%) and the rest being related with exchangeable, residual as well as fraction of organic matter.

The least available residual fraction also accounts for about $52 \%$ of total Co content in the tree bark samples. The $\mathrm{Ni}(61 \%)$ and $\mathrm{Pb}(47 \%)$ were found to be only in the readily available exchangeable fractions. The fractional profile showed that $\mathrm{Cu}(44 \%), \mathrm{Zn}(63 \%)$ and $\mathrm{Cd}(30 \%)$ had the highest percentage in the least available organic matter or sulphide fraction. The metal speciation study in tree bark samples clearly showed that $\mathrm{Ni}$ and $\mathrm{Pb}$ may be the most bioavailable metal followed by $\mathrm{Cu}, \mathrm{Zn}, \mathrm{Cd}$ and $\mathrm{Mn}$ under appropriate environmental conditions. Figure-3(a to f) showed the speciation of metals in tree bark into five different chemical fractions. 
RASĀYAN $J$. Chem.

Vol. 14 | No. 3 |1617-1628| July - September | 2021

Table-4: Statistical Summary of Heavy Metal Content in Various Fractions of Tree Bark concerning all 20 Locations in Guwahati $\left(\mu \mathrm{g} \mathrm{g}^{-1}\right)$

\begin{tabular}{c|c|c|c|c|c|c|c|c|c}
\hline & Fractions & $\mathrm{Mn}$ & $\mathrm{Fe}$ & $\mathrm{Co}$ & $\mathrm{Ni}$ & $\mathrm{Cu}$ & $\mathrm{Zn}$ & $\mathrm{Pb}$ & $\mathrm{Cd}$ \\
\hline Min & Exchangeable & 10.9 & 44.5 & 2.4 & 69.4 & 3 & 0 & 114.4 & 0.1 \\
\hline Max & & 18.5 & 95.6 & 4.4 & 137.8 & 44.5 & 0 & 118.6 & 0.5 \\
\hline Mean & & 14.3 & 65.3 & 3.5 & 104.4 & 12.7 & 0.0 & 117.0 & 0.3 \\
\hline SD & & 3.3 & 24.2 & 0.8 & 26.5 & 17.8 & 0.0 & 1.6 & 0.1 \\
\hline Min & Carbonate & 2.0 & 17 & 4.5 & 16.0 & 8.6 & 25.8 & 25.0 & 0.1 \\
\hline Max & & 5.1 & 64.6 & 9.3 & 32 & 14.6 & 87.3 & 34.5 & 1.6 \\
\hline Mean & & 3.6 & 42.7 & 7.4 & 22.8 & 11.6 & 50.2 & 28.8 & 0.7 \\
\hline SD & & 1.5 & 21.0 & 2.1 & 6.4 & 2.7 & 22.8 & 3.9 & 0.6 \\
\hline Min & Reducible & 15.4 & 298.6 & 2.0 & 8.9 & 12.9 & 193.5 & 23.6 & 0.2 \\
\hline Max & & 35.6 & 355.8 & 25 & 14.6 & 14.4 & 979 & 35.6 & 1.0 \\
\hline Mean & & 23.2 & 340.2 & 7.3 & 11.4 & 13.6 & 451.5 & 26.8 & 0.5 \\
\hline SD & & 7.6 & 23.8 & 9.9 & 2.3 & 0.6 & 320.6 & 4.9 & 0.4 \\
\hline Min & Organic Matter & 13.7 & 80.5 & 2.2 & 5.2 & 18.7 & 86.3 & 22.3 & 0.55 \\
\hline Max & & 22.1 & 341.9 & 16 & 34 & 60.5 & 1926.5 & 59.8 & 1.6 \\
\hline Mean & & 17.5 & 166.6 & 6.0 & 15.1 & 40.6 & 893.2 & 39.4 & 0.9 \\
\hline SD & & 3.2 & 112.1 & 5.7 & 13.8 & 19.0 & 812.0 & 15.5 & 0.4 \\
\hline Min & Residual & 2.5 & 13.4 & 3.4 & 2.15 & 10.3 & 8.2 & 34.7 & 0.4 \\
\hline Max & & 13.9 & 238.4 & 44 & 73 & 20.1 & 34.2 & 40.5 & 0.8 \\
\hline Mean & & 9.9 & 178.4 & 26.2 & 16.9 & 14.6 & 17.1 & 37.8 & 0.6 \\
\hline SD & & 4.4 & 93.9 & 20.2 & 31.4 & 4.3 & 10.2 & 2.9 & 0.2 \\
\hline
\end{tabular}

Environmental Pollution Indices

The pollution index $(\mathrm{Pi})$ study (Table-5) showed that the national highway roadside zone was indexed as high pollution $(\mathrm{Pi}>3)$ in terms of heavy metals $\mathrm{Ni}, \mathrm{Cd}, \mathrm{Zn}$ and $\mathrm{Cu}$ while low pollution $(\mathrm{Pi}=1-2)$ concerning $\mathrm{Pb}$ and $\mathrm{Mn}$. According to the ecological risk study (Eri), Table-5 revealed that a low $(<40)$ pollution index has been obtained for $\mathrm{Mn}, \mathrm{Zn}, \mathrm{Ni}, \mathrm{Cu}, \mathrm{Pb}$ and $\mathrm{Cr}$ for all the samples. In Cd content case, the risk was considerable $(\mathrm{Eri}=80-160)$ and it was also in the national highway roadside zone.

The potential ecological risk (RI) was ranged from 63.8 - 317.1 where the three zones (Industrial, Commercial and Sensitive) were under the low potential ecological risk category $(\mathrm{RI}<150)$ while the City roadside zone under the moderate risk category $(\mathrm{RI}=150-200)$. The highest level $(\mathrm{RI}=317.1)$ was obtained in the national highway roadside zone and felt under considerable potential ecological risk category $(\mathrm{RI}=300-600)$.

The Meta analytical study (Table-5) showed that the mean values of mobility ratio were excluded from the uptake or enrichment of any heavy metals as MR $<1$. The mobility factor (MF) index study showed that among the seven-studied metal the highest mobility appeared concerning Ni while lowest mobility towards $\mathrm{Co}$. The MF index was in order $\mathrm{Co}<\mathrm{Cu}<\mathrm{Zn}<\mathrm{Cd}<\mathrm{Mn}<\mathrm{Pb}<\mathrm{Ni}$. The heavy metal with high $\mathrm{MF}$ values indicates that the metal is highly labile as well as bioavailable. ${ }^{44}$

Table-5: Statistical Summary of Various Environmental Indices in Street Dust and Tree Bark samples concerning all 20 Locations in Guwahati $\left(\mu \mathrm{g} \mathrm{g}^{-1}\right)$

\begin{tabular}{c|c|c|c|c|c|c|c|c|c|c}
\hline & Indices & $\mathrm{Mn}$ & $\mathrm{Fe}$ & $\mathrm{Co}$ & $\mathrm{Ni}$ & $\mathrm{Cu}$ & $\mathrm{Zn}$ & $\mathrm{Pb}$ & $\mathrm{Cd}$ & $\mathrm{Cr}$ \\
\hline Min & $\mathrm{Pi}$ & 0.07 & 0.46 & 0.66 & 4.1 & 0.28 & 2 & 0.58 & 1.9 & 0.39 \\
\hline Max & & 1.65 & 1.1 & 1 & 4.4 & 6.2 & 16.4 & 1.5 & 7.9 & 0.84 \\
\hline Mean & & 0.6 & 0.7 & 0.8 & 4.2 & 3.2 & 4.6 & 1.0 & 4.0 & 0.6 \\
\hline SD & & 0.6 & 0.3 & 0.1 & 0.2 & 2.1 & 6.6 & 0.3 & 3.4 & 0.2 \\
\hline Min & $\mathrm{ERi}$ & 0.07 & 0 & 0 & 19.8 & 1.4 & 0.86 & 2.9 & 21 & 0.78 \\
\hline
\end{tabular}


RASĀYAN J.Chem.

Vol. 14 | No. 3 |1617-1628| July - September | 2021

\begin{tabular}{c|c|c|c|c|c|c|c|c|c|c}
\hline Max & & 1.65 & 0 & 0 & 22 & 31.1 & 16.4 & 7.3 & 237 & 1.7 \\
\hline Mean & & 0.6 & 0.0 & 0.0 & 21.2 & 15.9 & 4.6 & 5.0 & 121.2 & 1.2 \\
\hline SD & & 0.6 & 0.0 & 0.0 & 1.0 & 10.8 & 6.6 & 1.6 & 102.9 & 0.4 \\
\hline Min & MR & 0.082 & 0.008 & 0.64 & 0.0 & 0.08 & 0.099 & 0.549 & 0.092 & - \\
\hline Max & & 0.65 & 0.017 & 1.21 & 0.013 & 1.35 & 2.44 & 1.46 & 1.142 & - \\
\hline Mean & & 0.26 & 0.011 & 0.95 & 0.006 & 0.35 & 0.97 & 0.96 & 0.38 & - \\
\hline SD & & 0.24 & 0.004 & 0.21 & 0.006 & 0.56 & 0.89 & 0.39 & 0.43 & - \\
\hline Min & MF of & 53.1 & - & 18.2 & 49.6 & 31.4 & 12.9 & 64.1 & 32.6 & - \\
\hline Max & & 67.7 & - & 62.8 & 95.3 & 50.5 & 89.8 & 74.4 & 66.3 & - \\
\hline Mean & & 60.2 & - & 39.0 & 83.5 & 40.0 & 42.9 & 69.4 & 46.8 & - \\
\hline SD & & 5.6 & - & 16.6 & 19.5 & 8.2 & 33.8 & 4.8 & 16.2 & - \\
\hline
\end{tabular}

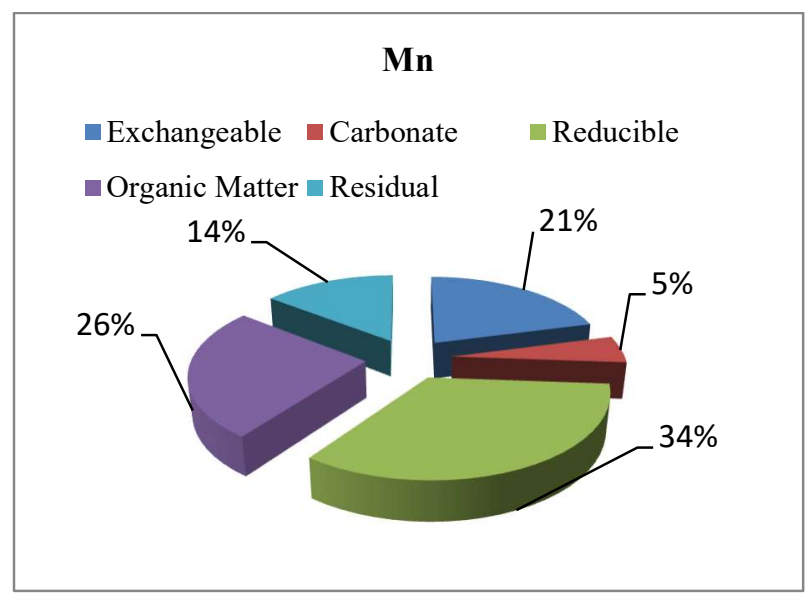

Fig.-3a: Fractional Distribution of Mn in Tree Bark

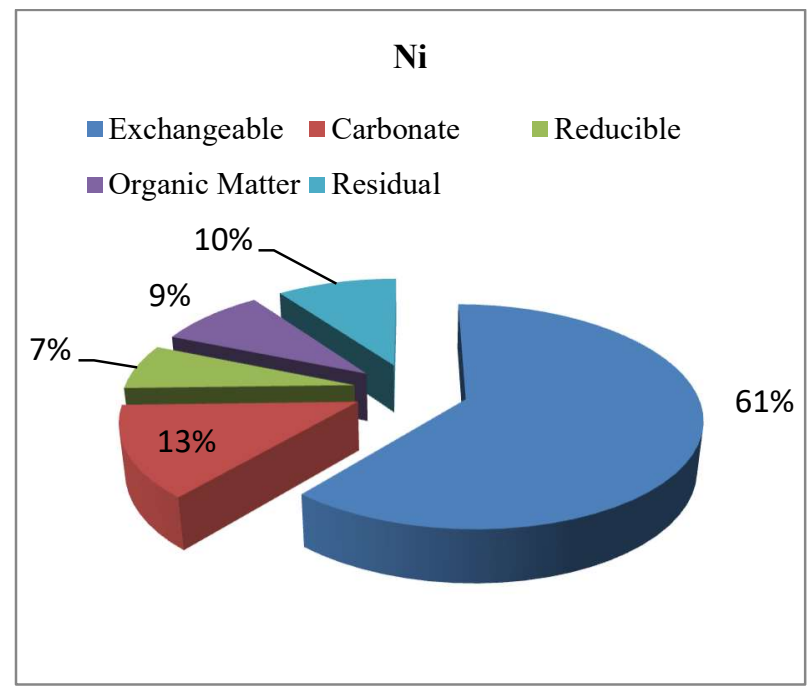

Fig.-3c: Fractional Distribution of Ni in Tree Bark

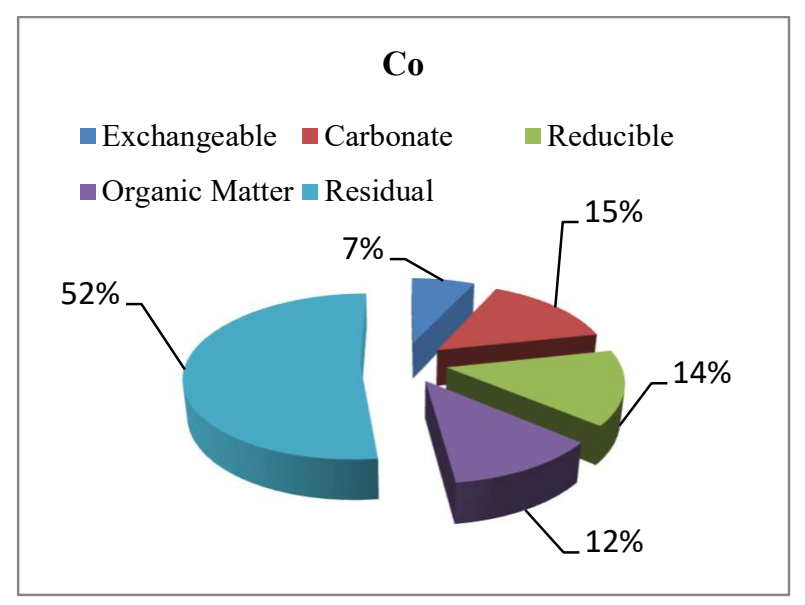

Fig.-3b: Fractional Distribution of Co in Tree Bark

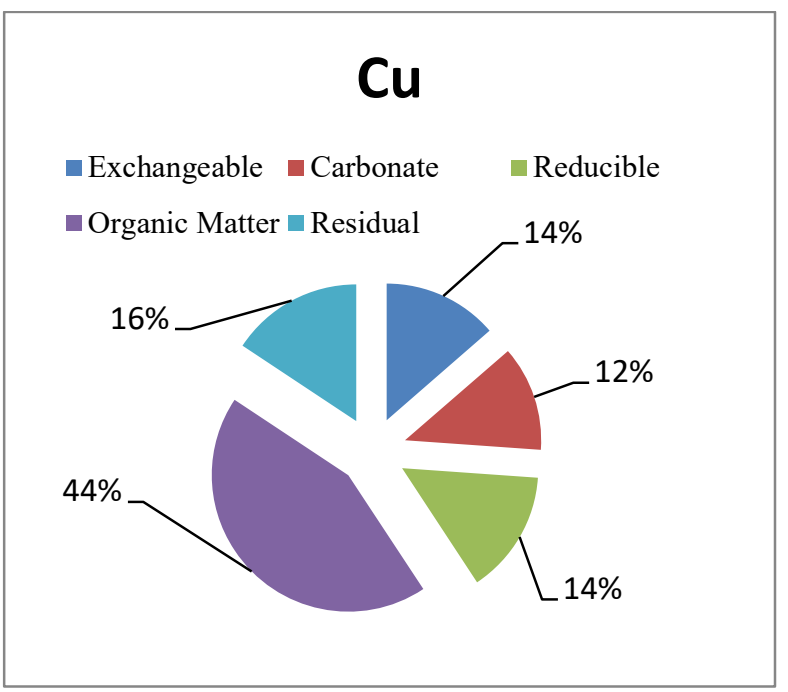

Fig.-3d: Fractional Distribution of $\mathrm{Cu}$ in Tree Bark 
RASĀYAN J. Chem.

Vol. 14 | No. 3 |1617-1628| July - September | 2021

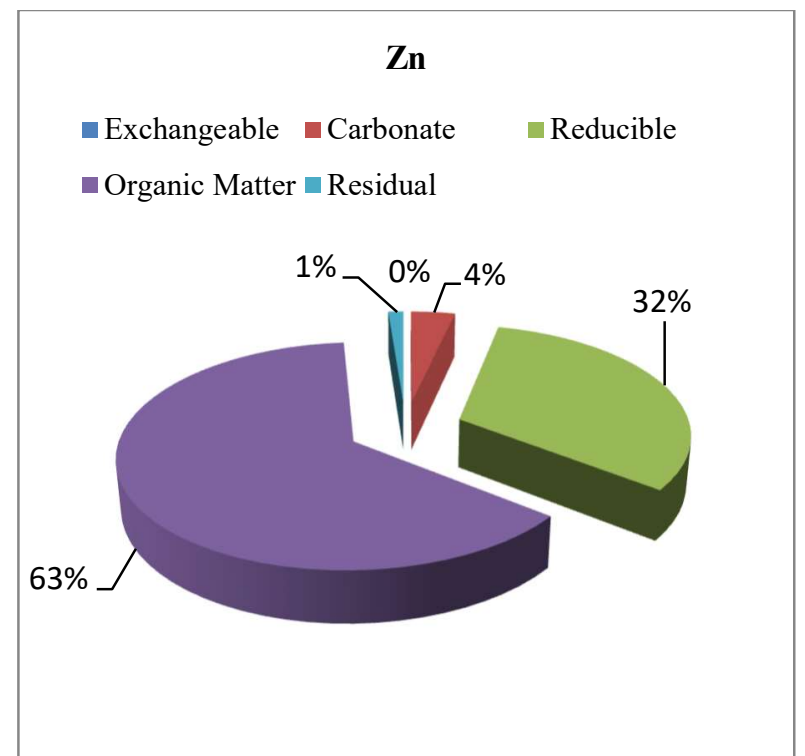

Fig.-3e: Fractional Distribution of $\mathrm{Zn}$ in Tree Bark

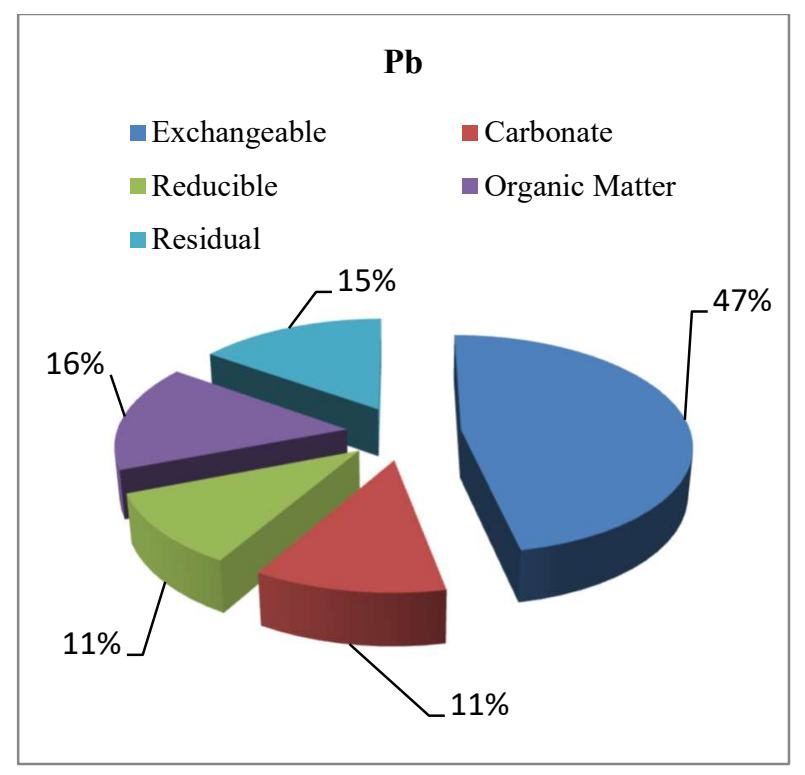

Fig.-3f: Fractional Distribution of $\mathrm{Pb}$ in Tree Bark

\section{CONCLUSION}

The present work comprehensively evaluated the total heavy metal content, as well as sequential extraction study and various environmental indices for $\mathrm{Pb}, \mathrm{Cr}, \mathrm{Cd}, \mathrm{Cu}, \mathrm{Zn}, \mathrm{Co}, \mathrm{Mn}$, along with $\mathrm{Fe}$, in different roadside, deposited road dust and adjacent tree bark belonging to five different types of zones in Guwahati. In deposited road dust, the concentration of heavy metal particularly $\mathrm{Cd}, \mathrm{Zn}, \mathrm{Cu}$, and $\mathrm{Ni}$ exceeded not only geochemical background values but also the maximum concentration level in uncontaminated dry soil. But in the case of roadside tree bark, all the nine studied metals were well below the geochemical background values except $\mathrm{Zn}$ content, which was on a little higher side. The fractional profile in tree bark showed that $\mathrm{Ni}$ and $\mathrm{Pb}$ were mostly associated with exchangeable fractions while $\mathrm{Mn}$ bound to a reducible fraction in considerable amounts. $\mathrm{Zn}, \mathrm{Cu}$, and $\mathrm{Cd}$ were mostly connected with organic matter/ sulphide fraction. In the present work higher percentage of metals in tree bark were mostly bound to exchangeable, carbonate as well as organic matter fractions. This can be a matter of concern that the metals $\mathrm{Co}, \mathrm{Ni}, \mathrm{Zn}, \mathrm{Cu}, \mathrm{Mn}, \mathrm{Cd}$, and $\mathrm{Pb}$ can be discharged to the surroundings under suitable environmental conditions as well as may alter the ecological equilibrium. Heavy metal contamination levels based on environmental indices indicated that $\mathrm{Ni}, \mathrm{Cd}, \mathrm{Cu}$ and $\mathrm{Zn}$ were in the high pollution category while $\mathrm{Pb}$ and $\mathrm{Mn}$ were low concerning pollution index. The potential ecological risk study categorized the five different zones as three zones (Industrial, Commercial and Sensitive) were under low potential ecological risk while City roadside zone under moderate risk. The national highway roadside zone was categorized under considerable potential ecological risk. Since Guwahati is free from any major industries, thus present study indicates that the anthropogenic factors (vehicular emissions, motor traffic-related activities) may be predominately responsible for the contamination of road dust as well as roadside tree bark with heavy metals. Additionally, the environmental significance of the results as well as the pollution level of other metals such as $\mathrm{Hg}$, Se needs to be further investigated.

\section{REFERENCES}

1. E. Adamiec, E. J. Krzeminska and O. Wieszala, Environmental Monitoring and Assessment, 188, 369(2016), https://doi.org/10.1007/s10661-016-5377-1

2. X. Shi , J. Wang, Environmental Earth Sciences, 68, 2409 (2013).

3. D. Vijay Singh, J. I. Ahmad Bhat, R. Ahmad Bhat, M. A. Dervash and S. Ahmad Ganei, Environmental Monitoring and Assessment, 190, 353 (2018)

4. T. Pulles , H. Denier van der Gon, W. Appelman and M. Verheul, Atmospheric Environment,61, 641(2012), https://doi.org/10.1016/j.atmosenv.2012.07.022

5. A. Ahmed, Elnazer, A. Salman, M. Elmontser, Seleem and M. E. Abu El Ella, Egypt International Journal of Ecology, Article ID 689420, (2015), https://doi.org/10.1155/2015/689420 
RASĀYAN J. Chem.

Vol. 14 | No. 3 |1617-1628| July - September | 2021

6. B. J. Alloway, Heavy Metals in Soils, Blackie Academic and Professional, London, UK, 2nd edition(1995).

7. E. Lombi and M. H. Gerzabek, Communications in Soil Science and Plant Analysis, 29(17), 2545 (1998).

8. W. Zglobicki, M. Telecka, S. Skupinski, A. Pasierbinska, M. Koziel, Environmental Earth Science, 77, 774(2018), https://doi.org/10.1007/s12665-018-7969-2

9. E. Said, S. A. Salman and A. A. Elnazer, Bulletin of the National Research Centre, 43, 43(2019), https://doi.org/10.1186/s42269-019-0081-2

10. M. Barbieri , Journal of Geology \& Geophysics, 5, 1(2016), https://doi.org/10.4172/23818719.1000237

11. J. P. Bennett, E. Chiriboga, J. Coleman, D. M. Waller, The Science of the Total Environment, 246, 261(2000), https://doi.org/10.1016/S0048-9697(99)00464-7

12. B. V. Tangahu, S. R. Sheikh Abdullah, H. Basri, M. Idris, N. Anuar and M. Mukhlisin, International Journal of Chemical Engineering, Article ID 939161(2011), https://doi.org/10.1155/2011/939161

13. M. J. McLaughlin, B. A. Zarcinas, D. P. Stevens, and N. Cook, Communications in Soil Science and Plant Analysis, 31(11), 1661 (2000).

14. M. J. McLaughlin, R. E. Hamon, R. G. McLaren, T. W. Speir, and S. L. Rogers, Australian Journal of Soil Research, 38 (6), 1037 (2000).

15. W. Ling, Q. Shen, Y. Gao, X. Gu, and Z. Yang, Australian Journal of Soil Research, 45 (8), 618 (2007).

16. A. Ozturk, C. Yarci and I. I. Ozyigit, Biotechnology \& Biotechnological Equipment, 31(5), 948(2018), https://doi.org/10.1080/13102818.2017.1353922

17. A. Tessier, P. G. C Campbell and M. Bisson, Analytical Chemistry, 51, 844 (1979).

18. S. C. Pan, C. C. Lin and D. H. Tseng, Resources, conservation and Recycling, 39, 79 (2003).

19. J. Yoon , X. Cao , Q. Zhou, L. Q. Ma, The Science of the Total environment, 368, 456 (2006), https://doi.org/10.1016/j.scitotenv.2006.01.016

20. R. K. Trievedy, P. K. Goel and C. L. Trisal, Practical Methods in Ecology and Environmental Science (1987).

21. T. C. Baruah, H. P. Barthakur, A textbook of Soil Chemical Analysis, (1997).

22. M.L. Jackson, Soil Chemical Analysis (1967).

23. D. R. S. Chen, M. A. Ming, Q. Lena, and W. Harris, Background Concentrations of Trace Metals In Florida Surface Soils: Comparison of Four EPA Digestion Methods and Baseline Concentration of Metals, Gainesville: Soil and Water Science Department University of Florida (1998).

24. Q. M. Jaradat, A. M. Massadeh, M. A. Zaitoun and B. Maitah, Environmental Monitoring and Assessment, 112, 197(2006).

25. D. Vollprecht, C. Riegler, F. Ahr, S. Stuhlpfarrer, M. Wellacher, International Journal of Environmental Science and Technology, 17, 3663(2020), https://doi.org/10.1007/s13762-020-02694-0

26. L. Yangsheng , M. Lanlan, L. Yaqiong , Z. Liting , Chemosphere, 67, 1025(2007), https://doi.org/10.1016/j.chemosphere.2006.10.056

27. K. A. Yusuf, Journal of Agronomy, 6(2), 331(2007)

28. G. O. Olutona, O. G. Aribisala, E. Adewuni, Akintunde, S. O. Obimakinde, Terrestrial and Aquatic Environmental Toxicology, 6(2), 116 (2012).

29. M. J. Mahanta, K. G. Bhattarcharyya, Environmental Monitoring and Assessment, 130, 129 (2010), https://doi.org/10.1007/s10661-010-1383-x

30. R. P. Narwal, B. R. Singh, and B. Salbu , Communications in Soil Science and Plant Analysis, 30, 1209 (1999), https://doi.org/10.1080/00103629909370279

31. F. Li, Z. Z. Fan, P. Xiao, K. Oh, X. Ma, and W. Hou, Environmental Geology, 57, 1815 (2009), https://doi.org/10.1007/s00254-008-1469-8

32. J. Huang, R. Huang, J. J. Jiao and K. Chen, Environmental Geology, 53, 221 (2007).

33. M.G. Gibson, J. G. Farmer, Environmental Pollution, 11(B), 117(1986), https://doi.org/10.1007/s00254-007-0636-7 
RASĀYAN J. Chem.

Vol. 14 | No. 3 |1617-1628| July - September | 2021

34. A. K. Krishna and P. K. Govil , Environmental Geology, 47(8), 1054(2005), https://doi.org/10.1007/s00254-005-1238-x

35. W. Zglobicki, M. Telecka, S. Skupinski, A. Pasierbinska, M. Kozie, Environmental Earth Sciences, 77, 774 (2018), https://doi.org/10.1007/s12665-018-7969-2

36. G. Muller, Umschau, 24, 778 (1979).

37. L. Hakason, Water Research, 14(8), 975 (1980), https://doi.org/10.1016/0043-1354(80)90143-8

38. N. F. Soliman, S. M. Nasr, M. A. Okbah , Journal of Environmental Health Science and Engineering, 13, 70 (2015), https://doi.org/10.1186/s40201-015-0223-X

39. M. Ergin , C. Saydam , O. Basturk , E. Erdem , R. Yoruk, Chemical Geology, 91, 269 (1991).

40. L. V. Hedges, I. Olkin, Statistical Methods for Meta-Analysis (1985).

41. M. W. Lipsey, D. B. Wilson, Practical Meta - Analysis. SAGE publications (2001).

42. D. L. Dowdy, T. E. Mckone, Environmental Toxicology and Chemistry, 16(12), 2448 (2009), https://doi.org/10.1002/etc.5620161203

43. C. Reimann, F. Koller, B. Frengstad, G. Kashulina, H. Niskavaara, P. Englmaier, The Science of the Total environment, 278, 87 (2001), https://doi.org/10.1016/s0048-9697(00)00890-1

44. C. Kabala and B. R. Singh, Journal of Environmental Quality, 30, 485 (2001), DOI: https://doi.org/10.2134/jeq2001.302485x

45. Y. Lu, F. Zhu, J. Chen, H. Gan and Y. Guo, Environmental Monitoring and Assessment, 134, 429 (2007), https://doi.org/10.1007/s10661-007-9634-1

46. B. D. Skrbic , M. N. Matavuly, S Milovac, Ecological Indicators,13(1), 168(2012), https://doi.org/10.1016/j.ecolind.2011.05.023

47. A. A. Olajire, E. T. Ayodle, G. O. Oyedirdan, E. Oluyemi, Environmental Monitoring and Assessment, 85(2), 135(2003).

48. Y. Lua, Z. Gonga, G. Zhanga , and W. Burghardtc, China, Geoderma, 115, 101 (2003).

49. J. E. Fergusson, R. W. Hayes, T. S Yong, New Zealand Journal of Science, 23, 293 (1980).

50. W. Fabis, Schadstoftbelastung von Boden- Auswirkurgen auf Boden- und wasserqalitat Alg Farstzeitschr. Munich: BLV Verlaggesellshaft, 128 (1987).

51. ICRCL (Inter- Departmental Committee on the Redevelopment of Contaminated Land), Guidance on the assessment and redevelopment of contaminated land. ICRCL Paper 59/83, Department of the Environment, London; (1983).

52. J. A. R. Martin, M. L Arias , J. M. G. Corbi , Environmental Pollution, 144, 1001, (2006), https://doi.org/10.1016/j.envpol.2006.01.045

53. O. A. Al-khashman, Environmental Earth Sciences, 70, 2603 (2013).

54. C. Bilos , J. C. Colombo, C. N Skorupka, M. J. R. Presa, Environmental Pollution, 111, 149 (2001), https://doi.org/10.1016/S0269-7491(99)00328-0

55. VCI, Copper History / Future, Van Commodities Inc. (2011).

56. O. A. Alkhashman, Atmospheric Environment, 38, 6803(2004), https://doi.org/10.1016/j.atmosenv.2004.09.011

57. E. De Miguel , J. F. Llamas, E. Chacon, T. Berg, S. Larsen, O. Royset, M. Vadset, Atmospheric Environment, 31, 2733(1997).

58. Q. Jaradat, K. Momani , Turkish Journal of Chemistry, 23, 209(1999).

59. J. B. Ellis, D. M. Revitt, Water, Air and Soil Pollution, 17, 87(1982).

60. Raymond A Wuana and Felix E Okieimen, International Scholarly Research Network ISRN Ecology (2011), https://doi.org/10.5402/2011/402647

61. A. K. Pendias A, H. Pendias, Biogeochemia Pierwiastkow Sladowych, Wyd. Nauk, PWN, Warszawa (1999).

62. W. L. Lindsay, and W. A. Norvell, Soil Science Society of America Journal, 42, 421(1978), https://doi.org/10.2136/sssaj1978.03615995004200030009x

[RJC-6256/2020] 